\title{
Financing Problems of Small and Medium Business in Kazakhstan
}

\author{
Abdibekov Saken Ualikhanovich ${ }^{1}$, Kantureev Mansur Tasybayevich $^{1}$, Bleutayeva Kulzhamal Begimbayevna ${ }^{1}$, \\ Bedelbayeva Assel Erikovna ${ }^{1} \&$ Kasenova Aybarshyn Mamlenovna ${ }^{1}$ \\ ${ }^{1}$ Zhetysu State University named after I. Zhansugurov, Taldykorgan, Zhansugurov Street, 187A, Kazakhstan \\ Correspondence: Abdibekov Saken Ualikhanovich, Zhetysu State University named after I. Zhansugurov, \\ 040000, Taldykorgan, Zhansugurov Street, 187A, Kazakhstan. E-mail: Saken_Abdibekov@mail.ru
}

\author{
Received: August 12, 2014 Accepted: August 30, 2014 Online Published: November 27, 2014 \\ doi:10.5539/ass.v10n24p96 URL: http://dx.doi.org/10.5539/ass.v10n24p96
}

\begin{abstract}
In article theoretical provisions and practical recommendations about improvement of forms and methods of financing of the enterprises of small and average business in modern conditions of development of economy of the Republic Kazakhstan were considered. For achievement of the put purpose in work the following tasks were solved: the main forms and methods of financing of subjects of small and average business were revealed, the main problems of forms and methods the financings constraining development of financing of small and average business in PK were defined, and also the main directions on improvement of forms and methods of financing of the enterprises of small and average business in PK are developed. The practical importance of article consists in possibility of use of the conclusions formulated in work, offers and recommendations when developing nation-wide actions for support and stimulation of development of small and average business of the state, an also financially-credit institutes in practice.
\end{abstract}

Keywords: small and medium business, entrepreneurship, finance, lending, second-tier banks, financial and lending institutions

\section{Introduction}

Small and average business is important sector of economy of the state. Without small and average business market economy neither to function, nor to develop not in a state. Small and average business stimulate development of skills of private business, form the competitive environment, quickly adapt for demand and offer changes in the market, create new working places and promote market filling by domestic goods and services (Tucker, 2011). These are one of sources of formation of an average class the societies promoting the solution of a problem of employment of the population.

From the first days of existence of young independent Kazakhstan one of leading roles in formation of its market economy, a support and development of small business is allocated for small business are legislatively recognized as the priority sphere of the state economic policy. And though in Kazakhstan influence of this sector on social and economic development of society isn't so essential as in industrially developed countries of the Western Europe, America and the Southeast Asia where more than a half of a gross internal product falls to his share, small business in our country became mass, dynamically developing part of business life (Colli, 2011).

In the present time according to data of official statistics in Kazakhstan the share of operating subjects of small business in the general number of subjects of the market makes $87 \%$, and in some branches is much more.

Small and average business only starts gathering turns in the development and formation. The biggest problem of the small and average enterprises is a lack of sources of their financing (Zachary, 2011).

Growth of influence of small and average business on development of world economy and recognition of its special role in the solution of a number of the major social and economic tasks caused big interest to problems of credit providing the small and average enterprises (Print and Reynolds, 2011). These problems were and remain a subject of research of many leading domestic and foreign scientists. The noticeable contribution to development of theoretical aspects of a problem of financing of business in the whole was made by L. I. Abalkin, G. N. Beloglazova, P. I. Vakhrin, F. A. Galanova, E. F. Zhukov, A. I. Zakirov, V. I. Kolesnikov, L. P. Krolivetskaya, O. I. Lavrushin. M. G. Lapusta, A. G. Porshnev, K. L. Starostin, V. of C. Torkanovsky, Ya. S. Melkumov. 
The general questions of bank crediting of the small enterprises found reflection in N. I. Kravtsovoy works, M. V. Klyuchnikova, A. I. Kartausova, M. L. Lishankckogo, I. B. Maslova, L. M. Morozova, V. M. Novikova, E. V. Prokopenko, T. M. Ryskinoy, P. M. Solyanovoy.

In such way, relevance of a subject is caused by the solution of an important economic problem-improvement of forms and methods of financing of small and average business in conditions of modernization of economy.

\section{Methods}

Theoretical base of research were monographs of modern domestic and foreign economists on questions of financing and crediting, the publication in scientifically-periodically press, standard and legal acts of RK regulating the credit relations of small business.

Statistical data of Agency RK on regulation and supervision of the financial market and the financial organizations, National bank RK, statistical data published in domestic and foreign literature, the financial reporting of the Kazakhstan banks of the second level formed information base of research.

The methodological basis of research was made by a dialectic method of knowledge and system approach. In a course of dissertation research methods of the system, factorial and comparative analysis were applied; set of methods of statistical processing of data; methods of graphic interpretation of the considered phenomena and processes. The analysis of statistical data is carried out with application of methods of group, comparison and generalization (Schmieding, 2012).

\section{Results}

Small and medium business-the most mobile sector of economy today, is a basis of client base for many commercial banks. Development of production of small business enterprises creates favorable conditions for economy improvement as the competitive environment develops, additional workplaces are created, there is a restructuring more actively, the consumer sector extends (Ashton, 2012).

The role of small and medium business in economy is considerable. They connect economy in a whole, forming some kind of base. First, the enterprises of small and medium business provide necessary mobility in the conditions of the market, creates deep specialization and cooperation without which their high efficiency is inconceivable. Secondly, they are capable not only to fill quickly the niches which are forming in the consumer sphere, but also rather quickly to pay off (Bertola \& Prete, 2012). Thirdly, to create the competition atmosphere. Fourthly (and it, perhaps, the most important), they create that Wednesday and spirit of business without which the market economy is impossible (Kyvik et al., 2013).

Development of small and medium business bears in itself a set of important advantages:

-increase in number of owners, so, formation of middle class;

-the main guarantor of political stability in democratic society;

-growth of a share of economically active population that increases the income of citizens and smoothes disproportions in welfare of various social groups;

-creation of new workplaces with rather low capital expenditure, especially in services industry;

-training due to use of workers with limited formal education who gain the qualification on a work place;

-development and deployment of technological, technical and organizational innovations (seeking to survive in competitive fight, small firms are more often inclined to take the risk and to carry out new projects);

-liquidation of monopoly of producers, creation of the competitive environment;

-interrelation improvement between various sectors of economy (Oluwatayo, 2013).

Now there is the whole range of the financial institutions rendering services to small and average business, the credit organizations, funds of support of business of foreign establishments and the funds which are carrying out in Kazakhstan various programs of financing of small business.

From these institutes on the volume of rendering financial services to small and medium business banks take a leading position.

Positive growth of the credit resources enclosed in real sector of economy as a whole, and in small business, in particular is observed. So, in 2013 in comparison with 2012 the credit resources sent to economy of the republic, increased by $7 \%$, in small business $-7.4 \%$. 
We will consider structure of a loan portfolio of the banking sector of RK for what we will address to data of the following table.

Table 1. Structure of a loan portfolio of the banking sector of RK billion tenge

\begin{tabular}{|c|c|c|c|}
\hline & 2011 & 2012 & 2013 \\
\hline $\begin{array}{l}\text { Loans to banks and the organizations carrying out separate types of bank } \\
\text { operations }\end{array}$ & 162.9 & 148.2 & 121.1 \\
\hline Loans to legal entities & 6705.2 & 7050.9 & 7472.9 \\
\hline Loans to physical persons & 2018.5 & 2530.4 & 3297.1 \\
\hline Loans to subjects of small and average business (residents of RK) & 1554.6 & 1870.7 & 2342.2 \\
\hline Operations "The Return Repo" & 31.6 & 57.7 & 114.8 \\
\hline Total loan portfolio (principal debt) & 10472.8 & 11657.9 & 13348.2 \\
\hline
\end{tabular}

Loan portfolio of the banking sector of RK on January 1, 2013. I made 11656.6 billion tenge, having increased in comparison with the beginning of year by 1183.8 billion tenge or for $11.3 \%$.

The volume of the credits of BVU to small business made 2342.2 billion tenge, and it is more similar indicator of last year for $25.2 \%$. At the expense of increase in annual volumes of the credits small businesses, for 2013 their share in the total amount of crediting of economy-from $14.8 \%$ increased to $17.5 \%$ also.

In branch structure of financing of small and average business nearly a half (49.7\%) credits for 2013 is the share of the trade sphere. Small production business remains out of the sphere of interests of financial and bank institutions, mainly, due to the lack of liquid mortgage base, smaller resistance to adverse factors and low extent of diversification of production. The incompleteness of this niche demands creation of the alternative credit organizations with use of various schemes and financing sources.

Despite RK developed and accepted by the government numerous state programs of development and support of small business, the main source of the capital nevertheless remain own resources. The main problems of development of small and medium-sized enterprise are inaccessibility to small and medium business of financial and credit resources, on conditions accepted for them. The credit policy of banks concerning small business is focused generally on financing of trade and purchasing activity. Banks of the second level grant the loans on a high rate (short-term from $25 \%$ to $32 \%$, medium-term from $16 \%$ to $17 \%$ ). Besides, banks demand mortgage providing which the majority has no beginning businessmen, as a rule, the cost of mortgage property twice more expensive than the obtained credit.

The sphere of small and average business needs the large enterprises as source of investments, a sales market of the production, and also "supplier" of leading businessmen. It demands, instead of operating other relations between small and large business therefore, finding of ways is necessary, to stimulate formation of the purposeful unions and the subcontract relations, allowing effective interaction between large and small business. In this case as investments the large enterprises can provide in rent to small enterprises fixed assets, the long-term credit on favorable terms and to enter the guarantor when receiving the guaranteed loan, to act in the subcontract relations. And also interactions of large and small business can be created on the basis of franchising and the leasing relations ( Chernova, 2013).

As activity of small and medium-sized enterprises is focused mainly on the local market many financial issues expediently to resolve with participation of local authorities. They have to define the main directions of support of business, develop a complex of necessary actions, and find material and financial resources for their realization at the expense of regional sources. One of mechanisms of attraction of the capitals at regional level is release and placement of municipal securities by local executive bodies with mediation of investment institutes (Wu et al., 2008).

Creation of specialized bank of financing of small business will allow to solve a set of problems of financial security of small business, in particular, support of beginning businessmen, to finance individual share of private investment companies in the capitals ( Muhammad et al., 2009).

It is known that opening business, businessmen lack for own capital, they practically have no opportunity to resort to loans. Naturally, they need financial support. 
Table 2. SWOT matrix-the analysis for detection of advantages and shortcomings of sources of financing of small enterprises

Strengths
Bank crediting
-existence of a set of the
various programs considering
requirements of the enterprise;
-possibility of attraction of
financial resources on financing
as the main, and current assets,
and also on replenishment of
the settlement account
(overdraft)

Leasing

-receiving economy from profit tax payment due to inclusion of leasing payments in prime cost; -as mortgage providing the property transferred on the contract of leasing acts;

-application of the accelerated depreciation

\section{Factoring}

-expeditious replenishment of current assets;

-increase in sales volume;

-lack of need of providing mortgage providing;

-decrease in risks in case of bezregressny factoring;

-management of receivables;

-simplicity of registration

Public financing

-possibility of receiving irrevocable gratuitous financing;

-financing of start-up and the operating enterprises;

-compensation of part of the expenses connected with financing from other sources -need of providing

mortgage

providing;

-high interest rates;

-considerable

package

documents;

-low activity of

crediting of the start-up projects -existence of possibility of subsidizing of an interest rate for the credit;

of -possibility of obtaining guarantee of guarantee and other funds;

-improvement of quality of maintaining account -the system of the taxation does inefficient leasing for many enterprises -existence of possibility of subsidizing of an interest rate for leasing; -gives the chance to update the main assets without existence of considerable own means; -reduces risk of moral and physical wear -possibility of economy on the property tax at registration on balance of the lessor.

\author{
-backwardness of \\ factoring \\ operations in RK -possibility of rapid \\ regions \\ -management of \\ receivables; \\ -simplicity \\ registration \\ of \\ of \\ growth of business; \\ -possibility of client \\ increase
}

-inability of performance of obligations under the leasing contract;

emergence of threat of bankruptcy -limitation of allocated budgetary funds; -within programs programs providing
guarantee guarantees;
-programs are focused not only on financial support, but also and on information, legal, personnel, etc. -decrease in financial stability;

-the increase in non-payments from contractors can lead to impossibility in established periods to extinguish obligations;

-emergence of threat of bankruptcy;

-toughening of the requirement of banks against the crisis phenomena in economy. 
Besides, the bank could provide means on favorable terms (4-5\% per annum) to the small business enterprises which are engaged in innovative development from the beginning to a conclusion of a product on the market. And also to finance individual share of private investment companies in the capitals of new and operating small and average businesses. Thus responsibility for risk in full has to lay down on investment companies. Besides, participation of specialized bank of financing would accelerate integration of large and small business (Robertson \& Athanassiou, 2009).

One of ways of attraction of financial resources in real sector of economy is annual compensation by the difference state between the market and preferential credit rate, provided by bank of the second level. It will allow banks to increase crediting volume, without incurring thus losses from decrease in profitability.

The analysis of earlier accepted state programs of support and business development in the republic testifies that on formation of regulatory legal base of small and average business specific proposals were made. However many points of earlier accepted state programs remained not executed due to the lack of the effective mechanism of realization and control ( Pykäläinen \& Ojala, 2009).

Further it should be noted that business in the country won't develop while courts won't correspond to economic system. Judicial and legal reform isn't finished. Specialized courts, first of all, the tax aren't created.

In the conditions of the market relations the lack of the qualified personnel capable both in the sphere of public administration, and of the sphere of management by the enterprises and business professionally is sharply felt to solve problems of economic development (Park, 2008).

For business development in priority sectors of economy it is necessary to consider possibility of decrease in rates of a value added tax to the imported equipment, the new technologies completing materials and raw materials, the equipment not being made in Kazakhstan and used in own production.

\section{Discussion}

Having generalized results of the analysis of sources of financial resources of small business in RK by means of a matrix of SWOT analysis by us the following forms of financial security were analysed: bank crediting, leasing, factoring, public financing.

Thus, the carried-out analysis allowed the author to mark out features of each type of financing of small enterprises, specific risks and potential opportunities of use in RK.

Banks on the way of financing of small business have following obstacles: risks which are a consequence of nedokstatochny mortgage providing, lack of necessary credit history and accurate accounts department of small enterprise; low interest in small business as direct consequence of a high risk; illiteracy of borrowers: many predpriknimatel don't understand conditions of receiving the credit or provide incomplete information on activity (Wu et al., 2007).

But, as practice of work of banks with small business shows, risks on the credits issued to it aren't so high, and the share of problem loans in many banks doesn't exceed 1-2\% ( Wynarczyk, 2007).

However nevertheless the majority small and average the regioknalnykh of banks considers financing of small and sredkny business as one of the main sources of the dokhod, and in regions banks are very interested in cooperation with small business.

\section{Conclusion}

The analysis of development of small and medium business allowed us to make the following suggestions for improvement of financing of small and medium business in the territory of the Republic of Kazakhstan:

1) Annually to compensate the state a difference between the market and preferential credit rate, provided by bank of the second level. It will allow banks to increase crediting volume, without incurring thus losses from decrease in profitability (Teo et al., 2008).

2) It is necessary to define degree of competence of workers at each level of hierarchical structure of bank, having provided them certain rights and strictly controlling responsibility of each worker. Such division of credit powers in commercial banks will increase overall performance of their credit divisions.

3) It is necessary to adjust high-quality information and analytical providing.

4) It is necessary that the credit department solved problems of strategic planning, methodical and instructive providing, the analysis and control over the implementation of conditions of business deal. It will raise level of the organization of credit work in many banks (Singer et al., 2007). 
5) On the basis of the Central bank it is necessary to create credit bureau which will contain data on unfair borrowers. NB RK can collect and store such information, and also report the credit organization for its inquiry data about enlisted in "black list".

6) Each Kazakhstan commercial bank within the credit policy has to develop own technique of the analysis of solvency of clients and in process of change of operating conditions, market conditions and priorities of credit policy to introduce necessary amendments.

7) It is necessary to apply modern financial instruments, in particular: the complex financial operations, allowing lowering a real rate of percent for the credit (it has to be available to the borrower and it is favorable to the creditor) by an optimum combination available bank of financial products. The resource is more available, the demand for it and the more so available credit investment potential can be fully used is higher.

8) Development of microcredit will allow increasing number of subjects of small and average business, and it will increase number of the busy population (Woldesenbet et al., 2007).

Thus, small and average business conducts to economy improvement as a whole and, therefore, the best exit for Kazakhstan is a creation of such policy of the state which would be directed on expansion and development of the enterprises of small and average business in our country.

\section{References}

Ashton, M. (2012). Real-Feel Inflation: Quantitative Estimation of Inflation Perceptions. Business Economics, 47, 14-26. http://dx.doi.org/10.1057/be.2011.35

Bertola, G., \& Prete, A. (2012, June). Finance, governments, and trade. Review of World Economics, 149(2), 273-294. http://dx.doi.org/10.1007/s10290-013-0153-6

Chernova, L. S. (2013, March). Interrelation between the typology of the RF subjects and methods for the evaluation of the national economic level. Studies on Russian Economic Development, 24(2), 189-198. http://dx.doi.org/10.1134/S1075700713020032

Colli, A. (2011). Business history in family business studies: from neglect to cooperation? Journal of Family Business Management, 1, 14-25. http://dx.doi.org/10.1108/20436231111122254

Kyvik, O., Saris, W., Bonet, W. E., \& Felício, J. A. (2013, April). The internationalization of small firms: The relationship between the global mindset and firms' internationalization behavior. Journal of International Entrepreneurship. http://dx.doi.org/10.1007/s10843-013-0105-1

Muhammad, N. M. N., Jantan, M., \& Taib, F. (2009) Environmental scanning and investment decision quality: Information processing perspective. Management Research News, 32(12), 1117-1129. http://dx.doi.org/10. $1108 / 01409170911006885$

Oluwatayo, I. (2013). Banking the unbanked in rural southwest Nigeria: Showcasing mobile phones as mobile banks among farming households. Journal of Financial Services Marketing, 18, 65-73. http://dx.doi.org/ $10.1057 /$ fsm.2013.2

Park, J. (2008). China, business and sustainability: Understanding the strategic convergence. Management Research News, 31(12), 951-958. http://dx.doi.org/10.1108/01409170810920657

Print, C., \& Reynolds, J. (2011). Family-controlled businesses and shareholder value. Journal of Family Business Management, 1, 47-64. http://dx.doi.org/10.1108/20436231111122281

Pykäläinen, T., \& Ojala, A. (2009). International activities of knowledge-intensive small-and medium-sized enterprises: The example of an open source software firm. Management Research News, 32(7), 645-658. http://dx.doi.org/10.1108/01409170910965242

Robertson, C. J., \& Athanassiou, N. (2009). Exploring business ethics research in the context of international business. Management Research News, 32(12), 1130-1146. http://dx.doi.org/10.1108/01409170911006894

Schmieding, H. (2012). Tough Love: The True Nature of the Eurozone Crisis. Business Economics, 47, 177-189. http://dx.doi.org/10.1057/be.2012.17

Singer, D., Avery, A., \& Baradwaj, B. (2008). Management innovation and cultural adaptively in international online banking. Management Research News, 31(4), 258-272. http://dx.doi.org/10.1108/01409170810 851339

Teo, St. T. T., Lakhani, B., Brown, D., \& Malmi, T. (2008). Strategic human resource management and knowledge workers: A case study of professional service firms". Management Research News, 31(9), 
683-696. http://dx.doi.org/10.1108/01409170810898572

Tucker, J. (2011). Keeping the business in the family and the family in business: "What is the legacy?" Journal of Family Business Management, 1, 65-73. http://dx.doi.org/10.1108/20436231111122290

Woldesenbet, K., Storey, J., \& Salaman, G. (2007). Senior managers' business knowledge in a transition economy. Management Research News, 30(4), 252-270. http://dx.doi.org/10.1108/01409170710736301

Wu, J., Song, J., \& Zeng, C. (2008). An empirical evidence of small business financing in China". Management Research News, 31(12), 959-975. http://dx.doi.org/10.1108/01409170810920666

$\mathrm{Wu}$, S., Matthews, \& Dagher, G. K. (2007). Need for achievement, business goals, and entrepreneurial persistence. Management Research News, 30(12), 928-941. http://dx.doi.org/10.1108/01409170710833358

Wynarczyk, P. (2007). Addressing the "gender gap" in the managerial labour market: The case of scientific small and medium-sized enterprises (SMEs) in the North East of England. Management Research News, 30(12), 942-954. http://dx.doi.org/10.1108/01409170710833367

Zachary, R. (2011). The importance of the family system in family business. Journal of Family Business Management, 1, 26-36. http://dx.doi.org/10.1108/20436231111122263

\section{Copyrights}

Copyright for this article is retained by the author(s), with first publication rights granted to the journal.

This is an open-access article distributed under the terms and conditions of the Creative Commons Attribution license (http://creativecommons.org/licenses/by/3.0/). 